\title{
The endoplasmic reticulum stress marker CHOP predicts survival in malignant mesothelioma
}

\author{
L E Dalton ${ }^{1,2}$, H J Clarke ${ }^{1,2}$, J Knight ${ }^{3}, \mathrm{M} \mathrm{H} \mathrm{Lawson}^{1}$, J Wason ${ }^{4}$, D A Lomas ${ }^{1,2}$, W J Howat ${ }^{5}$, R C Rintoul ${ }^{3}$, \\ D M Rass $\left.\right|^{3}$ and S J Marciniak ${ }^{*}, 1,2,3$
}

${ }^{1}$ Division of Respiratory Medicine, Department of Medicine, Addenbrooke's Hospital, Cambridge CB2 0QQ, UK; ${ }^{2}$ Cambridge Institute for Medical Research (CIMR), University of Cambridge, Wellcome Trust/MRC Building, Hills Road, Cambridge CB2 OXY, UK; ${ }^{3}$ Papworth Hospital NHS Foundation Trust, Papworth Everard, Cambridge CB23 3RE, UK; ${ }^{4}$ MRC Biostatistics Unit, Institute of Public Health, University Forvie Site, Robinson Way, Cambridge CB2 OSR, UK and ${ }^{5}$ Cambridge Research Institute, Li Ka Shing Centre, Cambridge CB2 ORE, UK

Background: Mesothelioma is an incurable cancer originating from the mesothelial cells that line the pleural, peritoneal and pericardial cavities. These cells synthesise large quantities of surface glycoproteins, rendering them dependent upon efficient endoplasmic reticulum (ER) function. When faced with elevated levels of secretory protein load, cells are said to experience ER stress, which has been implicated in the pathogenesis of many human diseases including cancer.

Method: We set out to measure markers of ER stress in malignant mesothelioma and to determine whether ER stress signalling correlates with clinical parameters.

Results: We observed that expression of the ER stress-responsive transcription factor C/EBP homologous protein (CHOP) correlated with patient survival and remained an independent prognostic variable in pairwise comparisons with all clinical variables tested. The most parsimonious multivariate model in our study comprised only performance status and CHOP staining. In contrast, expression of the ER stress-responsive phosphatase growth arrest and DNA damage 34 (GADD34) correlated with the degree of mesothelial differentiation, being lost progressively in biphasic and sarcomatoid mesotheliomas.

Conclusion: Our findings suggest that staining for $\mathrm{CHOP}$ provides prognostic information that may be useful in the stratification of patients with mesothelioma. Staining for GADD34 may prove useful in classification of mesothelioma histopathology.

The worldwide incidence of malignant mesothelioma is increasing and in the UK is expected to peak at over 3000 cases per annum within 5 years (Hodgson et al, 2005). However, it will continue to pose a global public health threat for decades thereafter, owing to the continued use of asbestos in developing economies. Much work has focused on developing new therapies, both pharmacological and surgical, yet clinical outcomes remain dire. Without a better understanding of the fundamental biology of this cancer, it is unlikely that significant breakthroughs will occur.

In vitro studies have shown that selective inhibition of the proteasome with the drug bortezomib will induce cell-cycle arrest in cultured malignant mesothelioma cell lines (Gordon et al, 2008). Although the mechanism remains unclear, when used to treat drug-resistant cases of malignant myeloma, bortezomib has been shown to induce endoplasmic reticulum (ER) stress, which can trigger both cell-cycle arrest and cell death (Obeng et al, 2006). Endoplasmic reticulum stress is now recognised to have a role in the pathophysiology of many human diseases including cancer (Marciniak and Ron, 2006). This reflects both increased protein misfolding within hypoxic solid tumours and dysregulation of the secretory pathway in malignant cells (Bi et al, 2005; Obeng et al, 2006). Moreover, an intact ER stress-signalling pathway is

*Correspondence: Dr SJ Marciniak; E-mail: sjm20@cam.ac.uk

Received 13 November 2012; revised 20 January 2013; accepted 23 January 2013; published online 14 February 2013

(c) 2013 Cancer Research UK. All rights reserved 0007-0920/13 


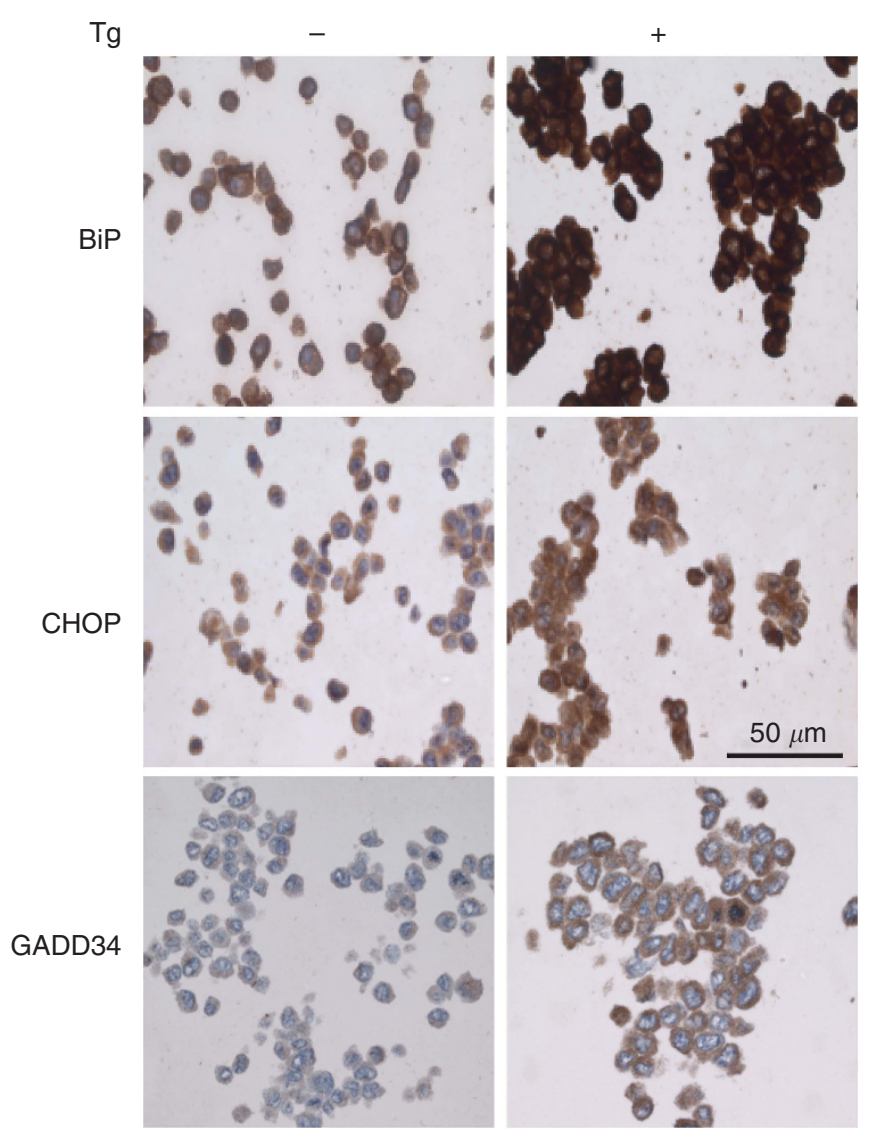

Figure 1. Endoplasmic reticulum stress and its detection in FFPE samples. Human HCT116 cell clots were generated using human plasma and thrombin from unstressed cells and cells treated with $400 \mathrm{~nm}$ thapsigargin $(\mathrm{Tg})$ to induce ER stress. Clots were fixed in formalin and embedded in paraffin to mimic the preparation of biopsy material. These were used to identify antibodies capable of distinguishing unstressed from ER-stressed cells by immunohistochemistry for BiP, CHOP and GADD34. Scale bar indicates $50 \mu \mathrm{m}$.

necessary for the growth of some tumours (Bi et al, 2005). The adaptive response to ER stress, or 'unfolded protein response', comprises mechanisms to regulate new protein translation and to induce genes that enable adaptation to stress (Marciniak and Ron, 2006; Marcinak and Ron, 2010). Mesothelial cells generate large quantities of surface glycoproteins to help lubricate the pleural space, and so dysregulation of their synthesis is likely to be associated with ER stress.

Endoplasmic reticulum stress activates multiple transmembrane sensors including protein kinase R-like kinase (PERK) (Marciniak and Ron, 2006). PERK mediates inhibition of global protein translation through phosphorylation of eukaryotic translation initiation factor $2 \alpha$ (eIF $2 \alpha)$, which reduces the load of newly synthesised proteins entering the ER lumen (Shi et al, 1998; Harding et al, 1999). Once phosphorylated, eIF $2 \alpha$ is unable to support new protein synthesis (Hinnebusch, 2000); although a subset of ER stress-responsive proteins including transcription factor C/EBP homologous protein (CHOP) is induced under these conditions (Wang et al, 1996). Target genes of CHOP, which include growth arrest of DNA damage 34 (GADD34), appear to have a role in the toxicity seen during chronic ER stress, because cells lacking CHOP are protected from ER-stress-induced death (Zinszner et al, 1998; Marciniak et al, 2004).

We hypothesised that markers of ER stress in biopsy specimens from cases of malignant mesothelioma would reflect the

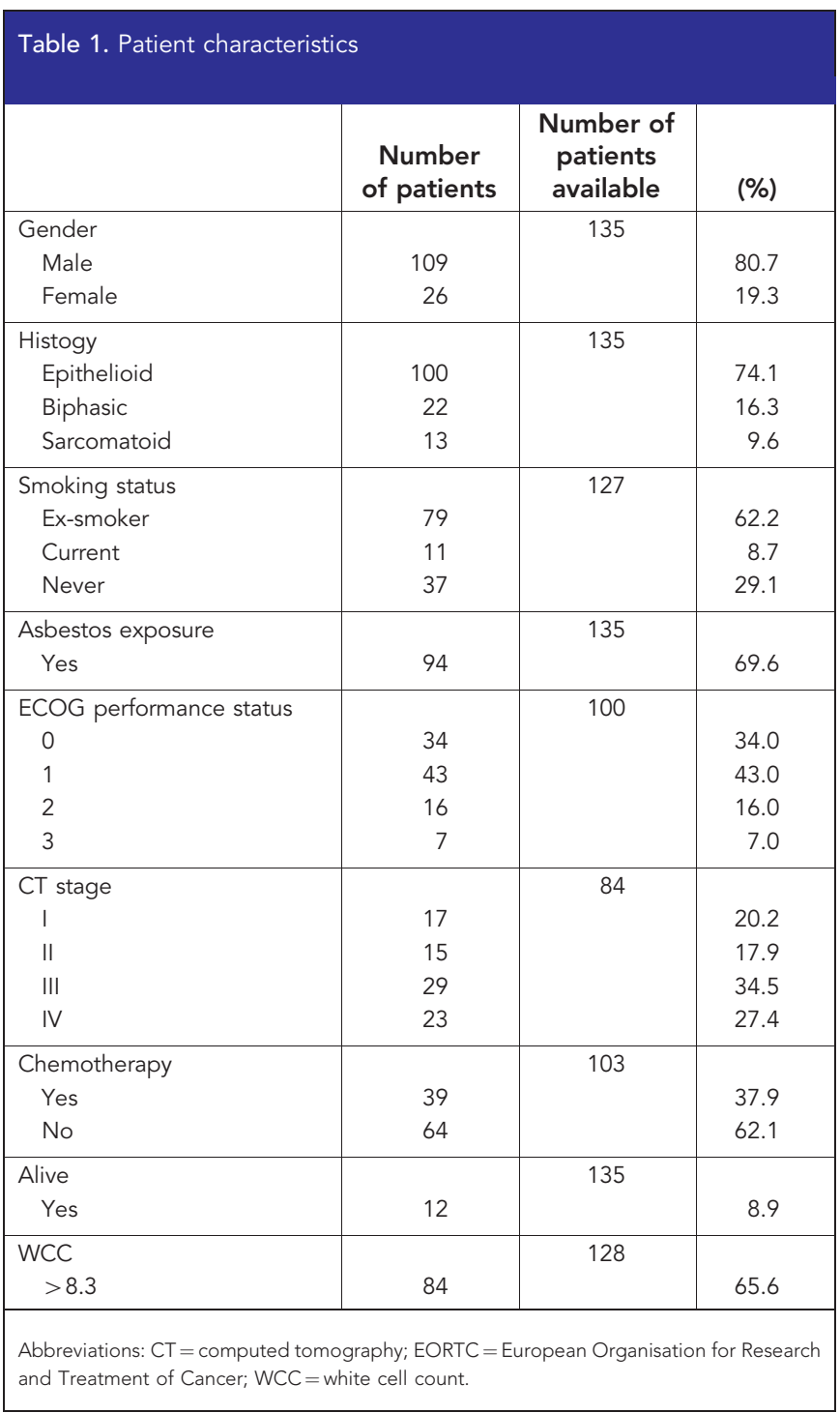

endogenous level of ER stress signalling within the tumour and provide prognostic information. We chose to measure protein expression of $\mathrm{CHOP}, \mathrm{GADD} 34$ and $\mathrm{BiP}$ in formalin-fixed paraffinembedded (FFPE) samples, because CHOP and GADD34 have both been linked with the toxic consequences of ER stress, whereas $\mathrm{BiP}$ levels are known to correlate with cytoprotection. Herein, we report that GADD34 expression is correlated with the degree of mesothelial cell differentiation, whereas CHOP expression is an independent predictor of prognosis in malignant mesothelioma.

\section{MATERIALS AND METHODS}

Ethics and consent. Ethical approval for the use of samples and data collection was granted by the Research Ethics Committee (REC reference 09/H0311/21). All cases of malignant mesothelioma diagnosed at Papworth Hospital (Cambridge, UK) between 2005 and 2010 were identified from hospital records, and the FFPE biopsy tissue blocks were retrieved from the pathology department store along with their associated histology slides. Clinical data relating to the cases were extracted from hospital records.

Antibodies. The antibodies used in this study were: rabbit polyclonal anti-GADD34 1:100 (10449-1-AP; Proteintech, Chicago, IL, USA); rabbit monoclonal anti-BiP 1:200 (C50B12; Cell Signaling Technology, Boston, MA, USA); and rabbit polyclonal 

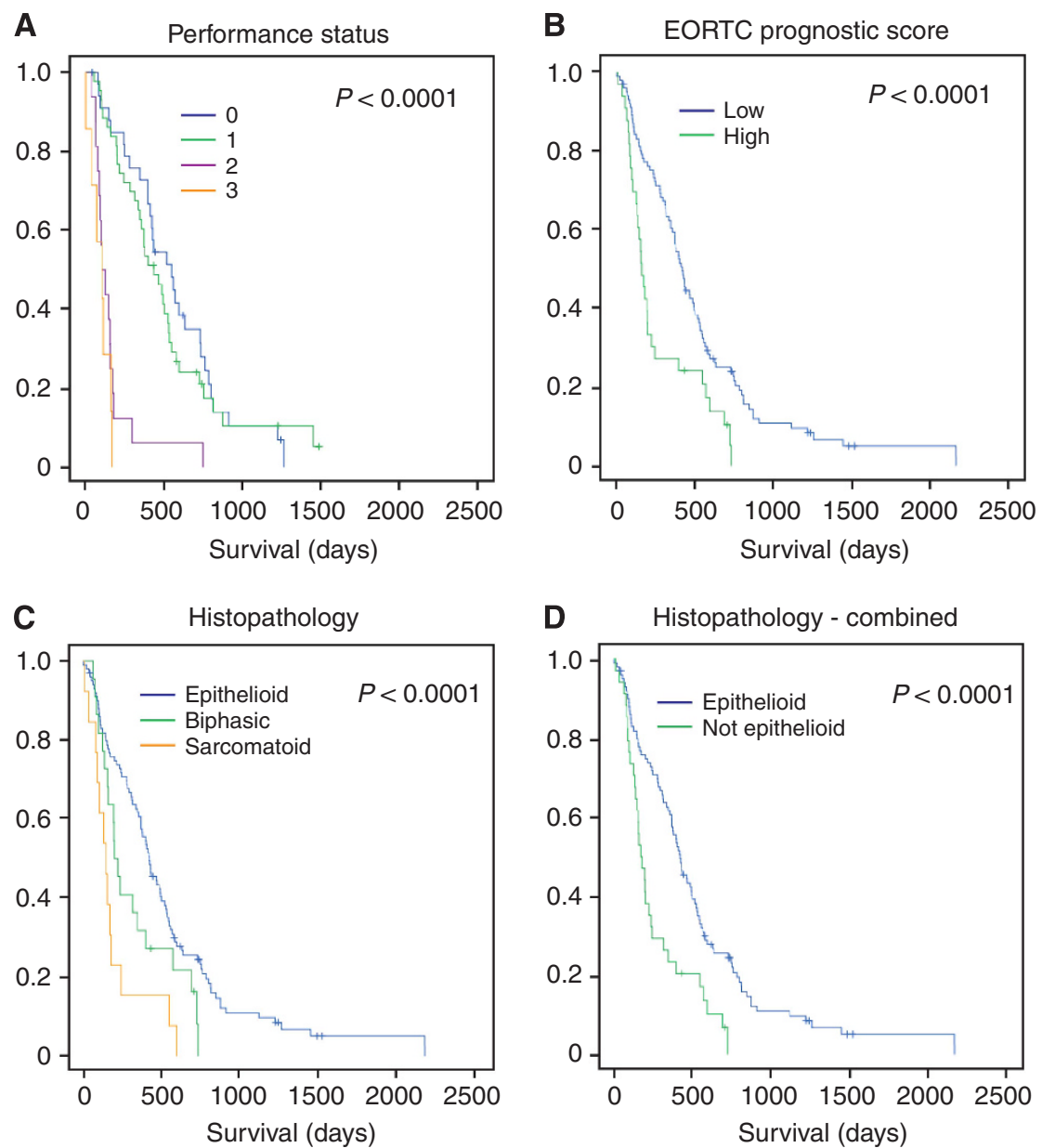

Figure 2. Mesothelioma patient characteristics and prognosis. Kaplan-Meier curves corresponding to demographic data. (A) ECOG performance status (0, blue; 1 , green; 2 , purple; and 3 , orange). (B) EORTC prognostic score $=0.55$ (if white cell count $>8.3 \times 10^{9}$ cells per I) +0.6 (ECOG performance status is 1 or 2 ) +0.52 (if histology probable) +0.60 (if histology is sarcomatoid) +0.60 (if gender is male); low $<1.27$, high $\geq 1.27$ (Fennell et al, 2005). (C) Histological sub-type. (D) Histological sub-type with sarcomatoid and biphasic combined as 'not epithelioid'. Statistical significance is indicated in figures $\mathbf{A}-\mathbf{D}$, top right. Univariate survival analysis used the log-rank test. Points censored from the statistics because the patient remained alive at the time of analysis are indicated as crosses.

anti-GADD153/CHOP 1:300 (ab59396; Abcam, Cambridge, UK). The following antibodies were tested using various conditions but were ineffective in detecting differences in antigen expression in response to ER stress: rabbit polyclonal anti-PPP1R15A/GADD34 (HPA202240, Prestige antibodies; Sigma, Dorset, UK); rabbit polyclonal anti-GADD34 (SC-824; Santa Cruz Technologies, Inc., Santa Cruz, CA, USA); and mouse monoclonal anti-GADD153/ CHOP (ab11419; Abcam).

Cell clots. Cultured cells were collected by trypsinisation and pelleted by centrifugation, washed with PBS and resuspended in Cytofix reagent (Surgipath, Milton Keynes, UK) for at least $2 \mathrm{~h}$ at room temperature. Cell clots were generated from these fixed cells by the addition of human plasma and bovine thrombin (Diagen Diagnostic Reagents Ltd, Oxfordshire, UK) with incubation at $37^{\circ} \mathrm{C}$ until clot formation. The clot was fixed in $10 \% \mathrm{v} / \mathrm{v}$ formalin, dehydrated through serial ethanol washes and embedded in paraffin wax.

Tissue microarray. One-hundred and thirty-five cases of malignant mesothelioma were included in the study. For each tissue block, a haematoxylin and eosin-stained section was re-examined by an experienced histopathologist, and at least three representative regions of tumour were identified. Cores of tissue measuring $0.6 \mathrm{~mm}$ in diameter were taken from each region of each block and were used to generate a tissue microarray (TMA) comprising three blocks. Normal pleura, liver and kidney controls were distributed at random intervals throughout the TMA. Sections of $3 \mu \mathrm{m}$ were prepared and stained as detailed below. Every 50th section was stained with haematoxylin and eosin for monitoring of morphology and quality of cores.

Immunohistochemistry. Sections were baked in an oven at $65^{\circ} \mathrm{C}$ for $1 \mathrm{~h}$. PT link tanks (Dako, Glostrup, Denmark) were used to perform deparaffinisation and heat-induced epitope retrieval (EnVision FLEX Target Retrieval Solution High pH; Dako). All slides were incubated for $20 \mathrm{~min}$ at $97^{\circ} \mathrm{C}$ and left in buffer (EnVision FLEX wash buffer; Dako) at room temperature for a minimum of $5 \mathrm{~min}$ to cool down. Staining was performed using an automated immunostainer (AutostainerLink48; Dako). The protocol was as follows: slides were incubated for $5 \mathrm{~min}$ in an endogenous block (EnVision FLEX peroxidase-blocking reagent; Dako) and then incubated with antibody for $30 \mathrm{~min}$. MNF116, mesothelin, vimentin and calretinin had an additional step of incubating sections with mouse linker (EnVision FLEX/mouse (linker); Dako) for $15 \mathrm{~min}$. Then all sections were incubated for $30 \mathrm{~min}$ in labelled polymer (EnVision FLEX/HRP; Dako). Each individual stage was followed by buffer rinses (EnVision FLEX wash buffer; Dako). Staining was visualised using the chromogen 
A

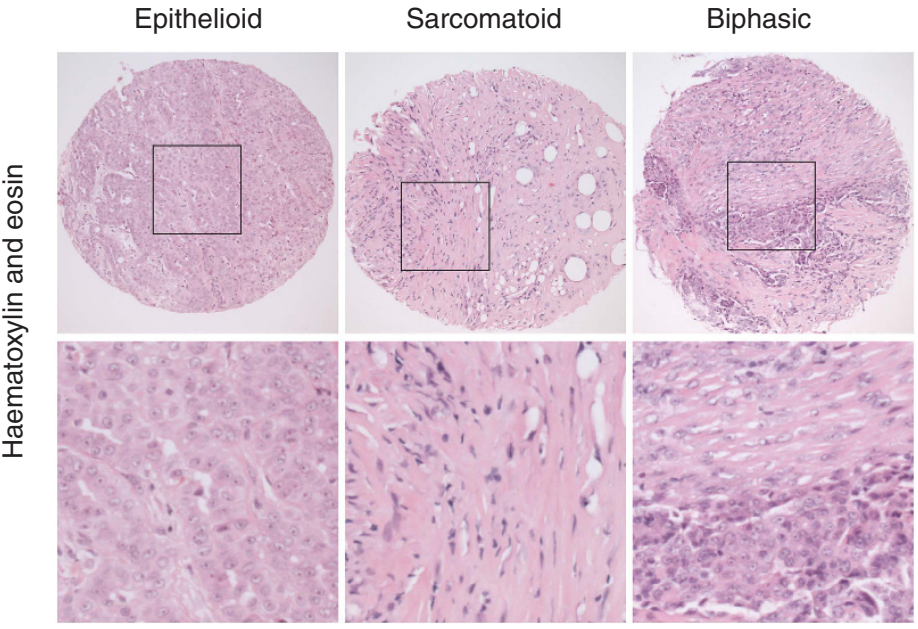

B

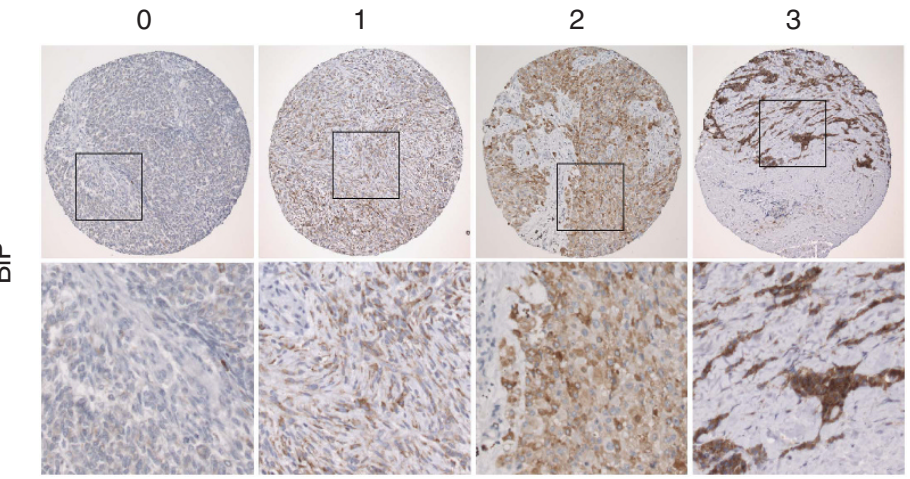

0

1

2

3
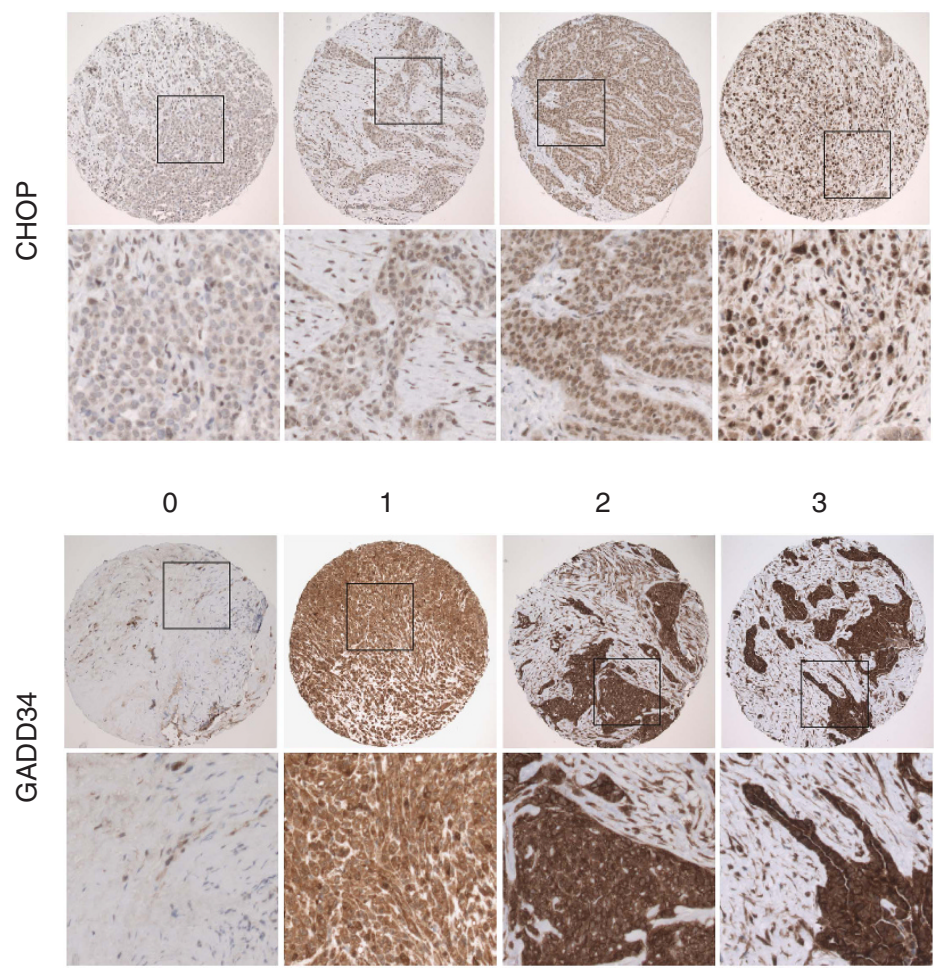

Figure 3. Tissue microarray stained for markers of ER stress. (A) Tissue microarray of $0.6 \mathrm{~mm}$ cores of representative epithelioid, sarcomatoid and biphasic malignant mesothelioma stained with $\mathrm{H} \& \mathrm{E} \times 40$ (insert box $\times 100$ ). (B) Representative images of tissue microarray cores stained for BiP, CHOP and GADD34, indicating intensities scored from 0 to 3 after the method by Allred et al (1998): 0, negative; 1, detectable but weak; 2 , moderate but submaximal; or 3 , maximal; $\times 40$ (insert $\times 100$ ). 

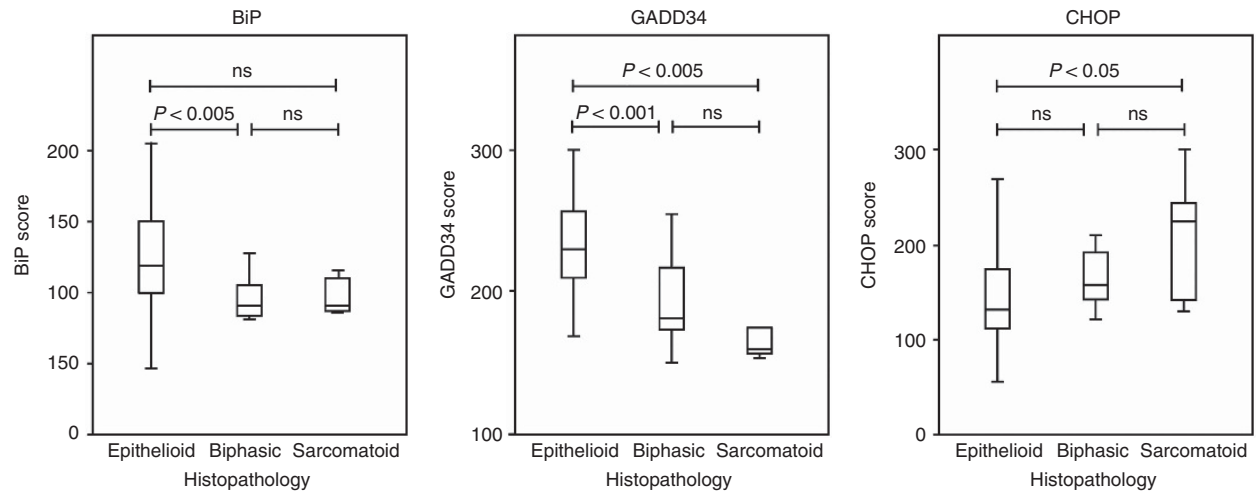

Figure 4. Correlation of ER stress markers with histological subtype. Box-and-whiskers plot of staining scores for BiP, GADD34 and CHOP in epithelioid, bisphasic and sarcomatoid mesothelioma. Statistical differences were calculated by ANOVA with Bonferroni post-hoc test.

3,3'-diaminobenzidine for 10 min, counterstained with haematoxylin (EnVision FLEX; Dako) for 5 min and manually cover-slipped (Surgipath) with DePeX mounting medium (VWR International, Poole, UK).

To quantify ER stress signalling in FFPE tissue samples, we tested the specificity of commercially available antibodies against the antigens BiP, CHOP and GADD34. To this end, human HCT116 cells and mouse embryonic fibroblasts were cultured under basal conditions or conditions known to induce ER stress. Thapsigargin inhibits the sarco/endoplasmic reticulum calcium ATPase that maintains ER luminal calcium levels, and so induces ER stress by causing depletion of ER calcium. Based on previous studies, under basal conditions, HCT116 cells were expected to show no or very low expression of CHOP and GADD34 with modest expression of BiP (Novoa et al, 2001, 2003; Harding et al, 2002; Marciniak et al, 2004). Antibodies for BiP, CHOP and GADD34 were examined for their ability to distinguish between unstressed cells and ER stressed cells (Figure 1). To mimic FFPE biopsy material, cell clots were fixed in formalin and embedded in paraffin. An antibody was assessed as detecting its antigen only if staining were higher in ER-stressed cells compared with controls. Antibodies tested that failed to pass these criteria are listed in Materials and Methods. For each antigen, the antibodies capable of reliably identifying ER-stressed FFPE samples were: rabbit polyclonal anti-GADD34 (10449-1-AP; Proteintech); rabbit monoclonal anti-BiP (C50B12; Cell Signaling Technology); and rabbit polyclonal anti-GADD153/CHOP (ab59396; Abcam).

Scoring and statistical analysis. Survival was assessed from the date of histological diagnosis. Data analysis was performed with SPSS v17.0 (SPSS Inc., Woking, UK) and the $\mathrm{R}$ software environment. Univariate survival analysis used the log-rank test (LR), and multivariable analysis was performed by Cox regression using a forward stepwise model based on likelihood ratios. Results were displayed graphically as Kaplan-Meier curves or box-andwhisker plots. To assess the utility of CHOP score as a prognostic marker, C-statistics (area under the ROC curve) were estimated from logistic regression models fitted to 1-year survival outcomes. A C-statistic value of 0.5 represents chance, whereas $>0.65$ is considered clinical relevant (Nowak et al, 2010). Estimated C-statistics, 95\% CIs and $P$-values for testing whether addition of CHOP significantly increased the C-statistic were calculated using the pROC package in $\mathrm{R}$ (Robin et al, 2011). The predictive value of models was assessed using C-statistic calculated from receiver operator curve analysis, with median survival as the bivariate state variable. Differences in staining scores between histological groups were assessed by ANOVA with Bonferroni post-hoc test.
Correlations between staining scores and histological subtypes were assessed by Spearman's correlation coefficient. $P$-values $<0.05$ were considered statistically significant.

\section{RESULTS}

Patients represented in the mesothelioma tissue microarray. Tissue blocks were identified for 135 cases of malignant mesothelioma biopsied at Papworth Hospital between 2005 and 2010. Of these, 84 had tumour tissue on at least one level of the TMA. In all cases where cores lacked tumour cells, the original material had been from CT-guided needle biopsies. Clinical data were complete to August 2012. The demographics of this group are presented in Table 1 and Figure 2. Consistent with the known epidemiology of malignant mesothelioma, most patients were male (80.7\%), had a positive history of exposure to asbestos (69.6\%) and had a median age of 70 years at the time of diagnosis (Table 1). The majority of cases had a positive smoking history (70.1\%), but only a minority were current smokers at the time of biopsy (8.7\%). Most cases had a good performance status of 0 or 1 at the time of diagnosis (77\%). Tumour International Mesothelioma Interest Group stage determined by CT scan at presentation was advanced (stages II-IV) in the majority of patients (79.8\%). Twelve patients $(8.9 \%)$ were alive at the time of data analysis.

Detection of ER stress markers in malignant mesothelioma. Scoring of the TMA for markers of ER stress was performed in parallel by two observers (LED and DMR) blinded to the clinical data. For each core and each antigen, intensity of tumour staining was evaluated on a scale from 0 to 3 after the method by Allred et al (1998): 0, negative; 1, detectable but weak; 2 , moderate but submaximal; or 3, maximal (Figure 3). In addition, the extent of staining was recorded as the proportion of malignant cells staining. Staining scores for each antigen were calculated as the sum of each intensity multiplied by the percentage of positive cells of that intensity, giving a range from $0(0 \times 100 \%)$ to $300(3 \times 100 \%)$. The score used in all subsequent analysis was the average across the available cores. When TMA slides were probed for expression of $\mathrm{BiP}, \mathrm{CHOP}$ and GADD34, each showed a significant relationship with histological subtype (Figure 4). There was a positive correlation between GADD34 immunoreactivity and mesothelial differentiation status (Spearman's correlation coefficient 0.513; $P=0.000$ ). GADD34 staining was significantly stronger in epithelial mesothelioma compared either with biphasic tumours $(P<0.001)$ or with sarcomatoid tumours $(P<0.005)$. BiP also showed correlation with mesothelial differentiation, but this 


\begin{tabular}{|c|c|c|}
\hline Parameter & Cut-off & $P$-value \\
\hline Histology & $\begin{array}{c}\text { All subtypes } \\
\text { Non-epithelioid }\end{array}$ & $\begin{array}{l}0.000 \\
0.000\end{array}$ \\
\hline Smoking & $\begin{array}{c}\text { All groups } \\
\text { Current smoker }\end{array}$ & $\begin{array}{l}0.031 \\
0.010\end{array}$ \\
\hline ECOG PS & $\begin{array}{l}\text { All groups } \\
0-1 \text { vs } 2-3\end{array}$ & $\begin{array}{l}0.000 \\
0.000\end{array}$ \\
\hline CT stage & $\begin{array}{l}\text { All groups } \\
\text { |-III vs IV }\end{array}$ & $\begin{array}{l}0.008 \\
0.004\end{array}$ \\
\hline Chemotherapy & Given & 0.001 \\
\hline EORTC prognostic score & $\begin{array}{l}\text { All groups } \\
<1.27\end{array}$ & $\begin{array}{l}0.002 \\
0.000\end{array}$ \\
\hline CHOP score & $\begin{array}{c}\text { All quintiles } \\
\text { Top vs bottom quintiles } \\
\text { Top quintile vs remainder }\end{array}$ & $\begin{array}{l}0.005 \\
0.006 \\
0.002\end{array}$ \\
\hline \multicolumn{3}{|c|}{$\begin{array}{l}\text { Abbreviations: } \mathrm{CHOP}=\mathrm{C} / \mathrm{EBP} \text { homologous protein; } \mathrm{CT}=\text { computed tomography } \\
\text { EORTC=European Organisation for Research and Treatment of Cancer; } \mathrm{PS}=\text { performance } \\
\text { status. }\end{array}$} \\
\hline
\end{tabular}

was less pronounced (Spearman's correlation coefficient $0.425 ; P=0.000)$. In contrast, staining for $\mathrm{CHOP}$ displayed a weak inverse correlation with mesothelial differentiation (Spearman's correlation coefficient $-0.333 ; P<0.006$ ).

Univariate analysis. Baseline demographic characteristics with prognostic significance on univariate analysis were histological subtype $(P<0.001)$, current smoking $(P=0.01)$, Eastern Cooperative Oncology Group (ECOG) performance status $(P<0.001)$, radiographic stage (CT stage) $(P=0.008$ for stages individually; $P=0.004$ for stage IV $v s$ I-III) and referral for chemotherapy $(P<0.001)$ (Table 2). In isolation, age and gender did not have an impact on survival (Supplementary Figure S1); however, as noted previously (Fennell et al, 2005), the composite European Organisation for Research and Treatment of Cancer (EORTC) prognostic score, which combines age, gender, histology, probability of diagnosis and leucocyte count, correlated significantly with prognoses $(P=0.002$ as a continuous variable and $P<0.001$ using the validated threshold of 1.27) (Fennell et al, 2005) (Table 2, Figure 2B).

For the purposes of univariate analysis, histological scores were grouped into quintiles. Only CHOP score quintiles were associated with prognosis $(P=0.005)$. Those cases staining in the top quartile of intensities had a median survival significantly shorter than that of the rest of the cohort $(145 \pm 17$ vs $486 \pm 55$ days, $P=0.002$; Figure $5 \mathrm{~A}-\mathrm{D})$. When cases were stratified by stage, a statistically significant difference persisted for early stage (stage I and II) (Figure 5E-H).

Multivariate analysis. In multivariate analysis by Cox regression, CHOP score was a significant predictor of survival independent of histology, smoking, ECOG performance status, chemotherapy and EORTC prognostic score (Table 3). CT stage and chemotherapy were redundant when models included CHOP score. When CHOP score, performance status, histology, smoking and EORTC prognostic score were considered simultaneously using a forward stepwise model, the most parsimonious model retained only CHOP score and performance status $\left(\mathrm{HR}_{\mathrm{CHOP}}\right.$ score 0.332 , $\left.P=0.014 ; \mathrm{HR}_{\text {performance status }} 2.501, P=0.000 ; n=46\right)$. However, the addition of CHOP score to logistic regression models of other prognostic factors improved the C-statistic significantly only in the case of radiological staging (Table 4).
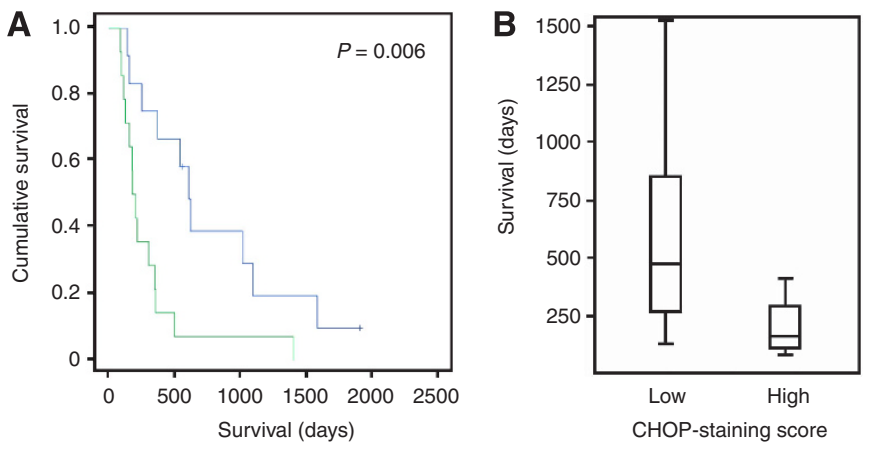

$\mathrm{CHOP}$ score: highest vs lowest quintiles
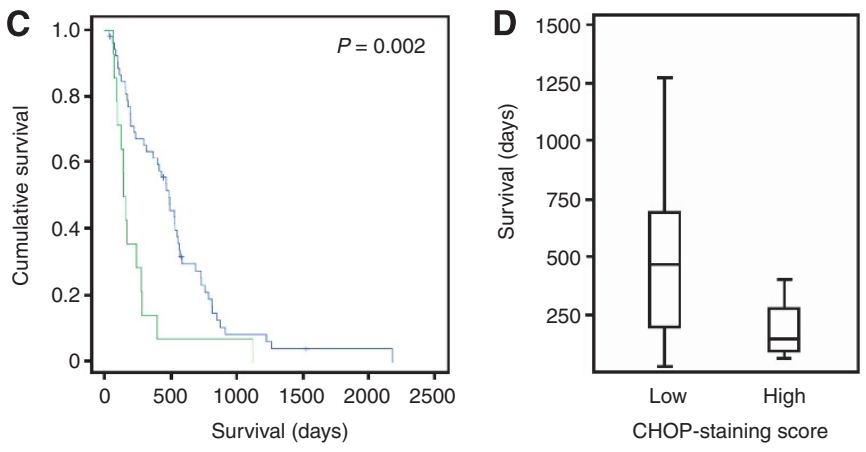

CHOP score: highest quintile vs all other cases
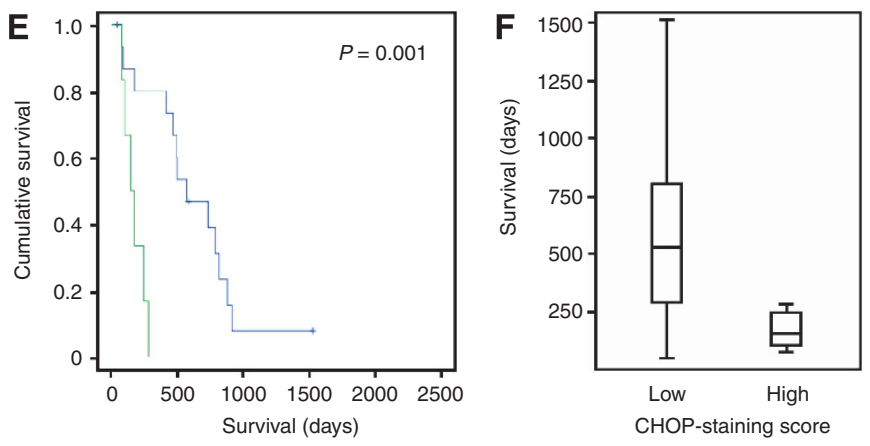

CHOP score: stage I and II
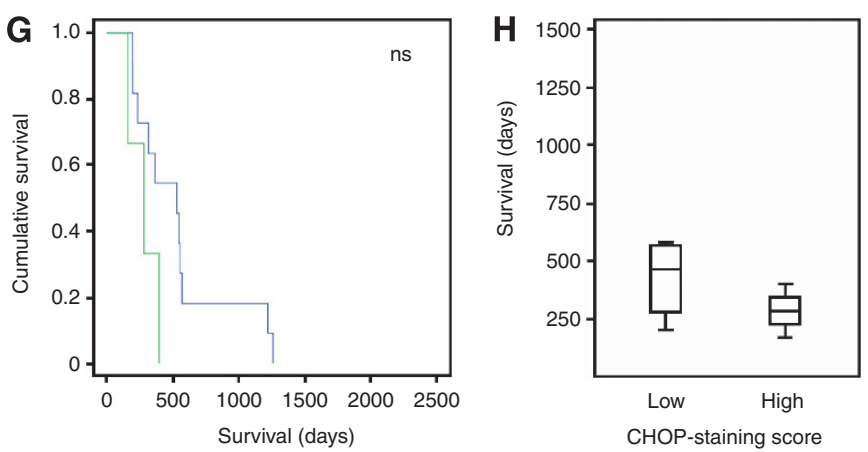

CHOP score: stage III and IV

Figure 5. CHOP score predicts prognosis. Kaplan-Meier curves and box-and-whiskers plots of mesothelioma patient groups defined by CHOP score. (A, B) Upper (green) and lower (blue) quintiles of CHOP score. Median survivals \pm s.e.: $\mathrm{CHOP}$ high $145 \pm 0.17$ days; $\mathrm{CHOP}$ low $486 \pm 48$ days. (C, D) Upper quintile (green) and remaining cases (blue). Median survival \pm s.e.: CHOP high $145 \pm 0.17$ days; CHOP low $486 \pm$ 55 days. Censored cases are represented by crosses. (E-H) Survival of CHOP-defined groups stratified by stage. (E, F) Stages I and II combined: CHOP high $145 \pm 45$ days; CHOP low $568 \pm 145$ days. (G, H) Stages III and IV combined: CHOP low $284 \pm 100$ days; CHOP low $536 \pm 127$ days. 


\section{DISCUSSION}

In this study, we have examined the expression levels of markers of ER stress in malignant mesothelioma, and correlated this with survival times. Levels of GADD34 correlated with mesothelial differentiation, whereas levels of $\mathrm{CHOP}$ staining predicted prognosis-independent histological subtype. Previous work has suggested that GADD34 may function as a tumour suppressor through its growth arrest and pro-apoptotic properties (Fornace et al, 1989; Zhan et al, 1994; Hollander et al, 1997; Su et al, 1997), although in our study it was not an independent predictor of survival. This may reflect a lack of statistical power, because selection of cases with the least GADD34 staining using an empirical cutoff of 175 appeared to identify a group with poor prognosis (not shown). Unfortunately, because of the rarity of mesothelioma, our cohort could not be efficiently divided into discovery and validation sets, and therefore this finding remains speculative and requires future validation. The close correlation between GADD34 staining and histological subtype suggests that GADD34 is unlikely to be an independent variable. Nevertheless, this correlation may indicate an important mechanistic link

\begin{tabular}{|c|c|c|c|c|c|}
\hline Paired comparison & $\begin{array}{c}\text { HR } \\
(\operatorname{Exp}(B))\end{array}$ & $\begin{array}{c}95 \% \\
\text { Cl low }\end{array}$ & $\begin{array}{c}95 \% \\
\text { Cl high }\end{array}$ & $P$-value & $n$ \\
\hline $\begin{array}{l}\text { CHOP score } \\
\text { Histology }\end{array}$ & $\begin{array}{l}0.469 \\
1.939\end{array}$ & $\begin{array}{l}0.243 \\
1.243\end{array}$ & $\begin{array}{l}0.902 \\
3.023\end{array}$ & $\begin{array}{l}0.023 \\
0.003\end{array}$ & 67 \\
\hline $\begin{array}{l}\text { CHOP score } \\
\text { Smoking }\end{array}$ & $\begin{array}{l}0.457 \\
1.647\end{array}$ & $\begin{array}{l}0.240 \\
1.021\end{array}$ & $\begin{array}{l}0.870 \\
2.657\end{array}$ & $\begin{array}{l}0.017 \\
0.041\end{array}$ & 65 \\
\hline $\begin{array}{l}\text { CHOP score } \\
\text { ECOG performance } \\
\text { status }\end{array}$ & $\begin{array}{l}0.383 \\
2.646\end{array}$ & $\begin{array}{l}0.162 \\
1.725\end{array}$ & $\begin{array}{l}0.908 \\
4.061\end{array}$ & $\begin{array}{l}0.000 \\
0.000\end{array}$ & 48 \\
\hline $\begin{array}{l}\text { CHOP score } \\
\text { EORTC prognostic } \\
\text { score }\end{array}$ & $\begin{array}{l}0.430 \\
3.477\end{array}$ & $\begin{array}{l}0.228 \\
1.845\end{array}$ & $\begin{array}{l}0.812 \\
6.550\end{array}$ & $\begin{array}{l}0.009 \\
0.000\end{array}$ & 67 \\
\hline $\begin{array}{l}\text { CHOP score } \\
\text { EORTC prognostic } \\
\text { score }<1.27\end{array}$ & $\begin{array}{l}0.424 \\
2.289\end{array}$ & $\begin{array}{l}0.225 \\
1.239\end{array}$ & $\begin{array}{l}0.799 \\
4.229\end{array}$ & $\begin{array}{l}0.008 \\
0.008\end{array}$ & 67 \\
\hline
\end{tabular}

Abbreviations: $\mathrm{Cl}=$ confidence interval; EORTC $=$ European Organisation for Research and Treatment of Cancer; $\operatorname{Exp}(B)=$ exponentiation of the $B$ coefficient; $H R=$ hazard ratio. between loss of mesothelial differentiation and tumour aggressiveness. It is tempting to speculate that correction of the deficit of GADD34 might have therapeutic benefit. Indeed, treatment with chemotherapy and radiotherapy has previously been shown to upregulate GADD34 expression in cancer cells and to promote increased oncolytic viral replication, presumably through antagonising the antiviral effects of PKR (Adusumilli et al, 2006, 2007). It is noteworthy that during an effort to identify genes involved in tumour progression, an $\mathrm{N}$-terminal truncated sequence of GADD34 was identified by subtractive hybridisation from a rat embryonic cell line (Su et al, 1997). This transcript, which was named progression elevated gene-3, was found to enhance tumour aggressiveness and promote angiogenesis in vivo ( $\mathrm{Su}$ et al, 1999). Similar truncating mutations of GADD34 are frequent occurrences during transformation of rat cell lines ( $\mathrm{Su}$ et al, 2005). The mechanism for the tumour-promoting activity is unclear but might plausibly involve a dominant-negative interaction with endogenous GADD34. We did not specifically attempt to detect this product of the GADD34 gene, and the antibody we used to detect GADD34 in histological specimens had been raised against a fusion protein, containing residues 304-569 of the 654 amino-acid human GADD34, and so would not have recognised most of the $\mathrm{N}$-terminal portion of the protein.

Although GADD34 is a transcriptional target of CHOP in the context of cellular stress (Marciniak et al, 2004), the two proteins demonstrated a weak reciprocal relationship in relation to mesothelial differentiation. It is possible that expression of GADD34 in benign mesothelium in vivo and in epithelioid malignant mesothelioma might occur through the alternate signalling pathways. Alternatively, the failure to express GADD34 through as-yet unidentified malignant processes might exaggerate the CHOP signal caused by ER stress. Since the transcriptional programme of CHOP includes at least 200 additional targets (Marciniak et al, 2004), it is possible that their overexpression in such circumstances might contribute to adaptation of the tumour to ER stress and thus promote tumour growth.

In summary, we have constructed a TMA of a series of cases of malignant mesothelioma, and used this to examine the expression levels of markers of ER stress in this cancer. Our results suggest that $\mathrm{CHOP}$ may represent a useful biomarker of tumour aggression. This may prove useful in patient stratification and the development of anticancer strategies aimed at modulating ER stress, for example, the use of proteasome inhibitors and newer agents such as inhibitors of HSP90. The correlation of GADD34 with mesothelial differentiation may prove useful in the subclassification of borderline histological cases.

Table 4. C-statistic value for the prediction of reaching median survival

\begin{tabular}{|c|c|c|c|c|}
\hline Model & C-statistic & $\Delta \mathrm{C}$ ( $P$-value $)$ & $\mathrm{Cl} 95 \%$ low & $\mathrm{Cl} 95 \%$ high \\
\hline CHOP top quintile & 0.649 & & 0.555 & 0.743 \\
\hline $\begin{array}{l}\text { Histology (all types) } \\
\text { Histology (all types) }+ \text { CHOP top quintile }\end{array}$ & $\begin{array}{l}0.706 \\
0.750\end{array}$ & 0.050 (ns) & $\begin{array}{l}0.606 \\
0.653\end{array}$ & $\begin{array}{l}0.801 \\
0.859\end{array}$ \\
\hline $\begin{array}{l}\text { ECOG PS } \\
\text { ECOG }+ \text { CHOP top quintile }\end{array}$ & $\begin{array}{l}0.826 \\
0.895\end{array}$ & 0.069 (ns) & $\begin{array}{l}0.712 \\
0.805\end{array}$ & $\begin{array}{l}0.941 \\
0.985\end{array}$ \\
\hline $\begin{array}{l}\text { EORTC score }<1.27 \\
\text { EORTC score }<1.27+\text { CHOP top quintile }\end{array}$ & $\begin{array}{l}0.667 \\
0.718\end{array}$ & 0.052 (ns) & $\begin{array}{l}0.567 \\
0.613\end{array}$ & $\begin{array}{l}0.767 \\
0.825\end{array}$ \\
\hline $\begin{array}{l}\text { CT stage (all) } \\
\text { CT stage (all) }+\mathrm{CHOP} \\
\text { CT stage (I-III vs IV) } \\
\text { CT stage (I-III vs IV) + CHOP }\end{array}$ & $\begin{array}{l}0.748 \\
0.855 \\
0.608 \\
0.797\end{array}$ & $\begin{array}{l}0.107 \text { (ns) } \\
0.188(0.011)\end{array}$ & $\begin{array}{l}0.581 \\
0.725 \\
0.483 \\
0.657\end{array}$ & $\begin{array}{l}0.915 \\
0.985 \\
0.797 \\
0.936\end{array}$ \\
\hline
\end{tabular}




\section{ACKNOWLEDGEMENTS}

This work was supported by the June Hancock Mesothelioma Research Fund and by the British Lung Foundation. SJM is an MRC Senior Clinical Fellow (G1002610). DAL is supported by the Medical Research Council (UK), the Cambridge NIHR Biomedical Research Centre, the Engineering and Physical Sciences Research Council (UK) and Papworth NHS Trust. RCR and DMR are funded, in part, by the Cambridge NIHR Biomedical Research Centre. JK was funded, in part, by the Cambridge Cancer Research UK Institute.

\section{REFERENCES}

Adusumilli PS, Chan MK, Chun YS, Hezel M, Chou TC, Rusch VW, Fong Y (2006) Cisplatin-induced GADD34 upregulation potentiates oncolytic viral therapy in the treatment of malignant pleural mesothelioma. Cancer Biol Ther 5(1): 48-53.

Adusumilli PS, Chan MK, Hezel M, Yu Z, Stiles BM, Chou TC, Rusch VW, Fong Y (2007) Radiation-induced cellular DNA damage repair response enhances viral gene therapy efficacy in the treatment of malignant pleural mesothelioma. Ann Surg Oncol 14(1): 258-269.

Allred DC, Harvey JM, Berardo M, Clark GM (1998) Prognostic and predictive factors in breast cancer by immunohistochemical analysis. Mod Pathol 11(2): 155-168.

Bi M, Naczki C, Koritzinsky M, Fels D, Blais J, Hu N, Harding H, Novoa I, Varia M, Raleigh J, Scheuner D, Kaufman RJ, Bell J, Ron D, Wouters BG, Koumenis C (2005) ER stress-regulated translation increases tolerance to extreme hypoxia and promotes tumor growth. EMBO J 24(19): 3470-3481.

Fennell DA, Parmar A, Shamash J, Evans MT, Sheaff MT, Sylvester R, Dhaliwal K, Gower N, Steele J, Rudd R (2005) Statistical validation of the EORTC prognostic model for malignant pleural mesothelioma based on three consecutive phase II trials. J Clin Oncol 23(1): 184-189.

Fornace AJ, Neibert DW, Hollander MC, Luethy JD, Papathanasiou M, Fragoli J, Holbrook NJ (1989) Mammalian genes coordinately regulated by growth arrest signals and DNA-damaging agents. Mol Cell Biol 9: 4196-4203.

Gordon GJ, Mani M, Maulik G, Mukhopadhyay L, Yeap BY, Kindler HL, Salgia R, Sugarbaker DJ, Bueno R (2008) Preclinical studies of the proteasome inhibitor bortezomib in malignant pleural mesothelioma. Cancer Chemother Pharmacol 61(4): 549-558.

Harding H, Zhang Y, Ron D (1999) Translation and protein folding are coupled by an endoplasmic reticulum resident kinase. Nature 397(6716): 271-274.

Harding HP, Calfon M, Urano F, Novoa I, Ron D (2002) Transcriptional and translational control in the mammalian unfolded protein response. Annu Rev Cell Dev Biol 18: 575-599.

Hinnebusch AG (2000) Mechanism and regulation of initiator methionyltRNA binding to ribosomes. In: Sonenberg N, Hershey JWB, Mathews MB (eds). Translational Control of Gene Expression. CSHL Press: Cold Spring Harbor, pp 185-243.

Hodgson JT, McElvenny DM, Darnton AJ, Price MJ, Peto J (2005) The expected burden of mesothelioma mortality in Great Britain from 2002 to 2050. Br J Cancer 92(3): 587-593.

Hollander MC, Zhan Q, Bae I, Fornace Jr AJ (1997) Mammalian GADD34, an apoptosis- and DNA damage-inducible gene. J Biol Chem 272(21): 13731-13737.
Marcinak SJ, Ron D (2010) The unfolded protein response in lung disease. Proc Am Thorac Soc 7(6): 356-362.

Marciniak SJ, Ron D (2006) Endoplasmic reticulum stress signaling in disease. Physiol Rev 86(4): 1133-1149.

Marciniak SJ, Yun CY, Oyadomari S, Novoa I, Zhang Y, Jungreis R, Nagata K, Harding HP, Ron D (2004) CHOP induces death by promoting protein synthesis and oxidation in the stressed endoplasmic reticulum. Genes Dev 18: 3066-3077.

Novoa I, Zeng H, Harding H, Ron D (2001) Feedback inhibition of the unfolded protein response by GADD34-mediated dephosphorylation of eIF2a. J Cell Biol 153(5): 1011-1022.

Novoa I, Zhang Y, Zeng H, Jungreis R, Harding HP, Ron D (2003) Stress-induced gene expression requires programmed recovery from translational repression. EMBO J 22(5): 1180-1187.

Nowak AK, Francis RJ, Phillips MJ, Millward MJ, van der Schaaf AA, Boucek J, Musk AW, McCoy MJ, Segal A, Robins P, Byrne MJ (2010) A novel prognostic model for malignant mesothelioma incorporating quantitative FDG-PET imaging with clinical parameters. Clin Cancer 16(8): 2409-2417.

Obeng EA, Carlson LM, Gutman DM, Harrington Jr WJ, Lee KP, Boise LH (2006) Proteasome inhibitors induce a terminal unfolded protein response in multiple myeloma cells. Blood 107(12): 4907-4916.

Robin X, Turck N, Hainard A, Tiberti N, Lisacek F, Sanchez JC, Muller M (2011) pROC: an open-source package for R and S + to analyze and compare ROC curves. BMC Bioinformatics 12: 77.

Shi Y, Vattem KM, Sood R, An J, Liang J, Stramm L, Wek RC (1998) Identification and characterization of pancreatic eukaryotic initiation factor 2 alpha-subunit kinase, PEK, involved in translational control. Mol Cell Biol 18(12): 7499-7509.

Su ZZ, Emdad L, Sarkar D, Randolph A, Valerie K, Yacoub A, Dent P, Fisher PB (2005) Potential molecular mechanism for rodent tumorigenesis: mutational generation of progression elevated Gene-3 (PEG-3). Oncogene 24(13): 2247-2255.

Su ZZ, Goldstein NI, Jiang H, Wang MN, Duigou GJ, Young CS, Fisher PB (1999) PEG-3, a nontransforming cancer progression gene, is a positive regulator of cancer aggressiveness and angiogenesis. Proc Natl Acad Sci USA 96(26): 15115-15120.

Su ZZ, Shi Y, Fisher PB (1997) Subtraction hybridization identifies a transformation progression- associated gene PEG-3 with sequence homology to a growth arrest and DNA damage-inducible gene. Proc Natl Acad Sci USA 94(17): 9125-9130.

Wang X-Z, Lawson B, Brewer J, Zinszner H, Sanjay A, Mi L, Boorstein R, Kreibich G, Hendershot L, Ron D (1996) Signals from the stressed endoplasmic reticulum induce C/EBP homologous protein (CHOP/ GADD153). Mol Cell Biol 16: 4273-4280.

Zhan Q, Lord KA, Alamo Jr I, Hollander MC, Carrier F, Ron D, Kohn KW, Hoffman B, Liebermann DA, Fornace Jr AJ (1994) The gadd and $\mathrm{MyD}$ genes define a novel set of mammalian genes encoding acidic proteins that synergistically suppress cell growth. Mol Cell Biol 14(4): 2361-2371.

Zinszner H, Kuroda M, Wang X, Batchvarova N, Lightfoot RT, Remotti H, Stevens JL, Ron D (1998) CHOP is implicated in programmed cell death in response to impaired function of the endoplasmic reticulum. Genes Dev 12(7): 982-995.

This work is published under the standard license to publish agreement. After 12 months the work will become freely available and the license terms will switch to a Creative Commons AttributionNonCommercial-Share Alike 3.0 Unported License.

Supplementary Information accompanies this paper on British Journal of Cancer website (http://www.nature.com/bjc) 